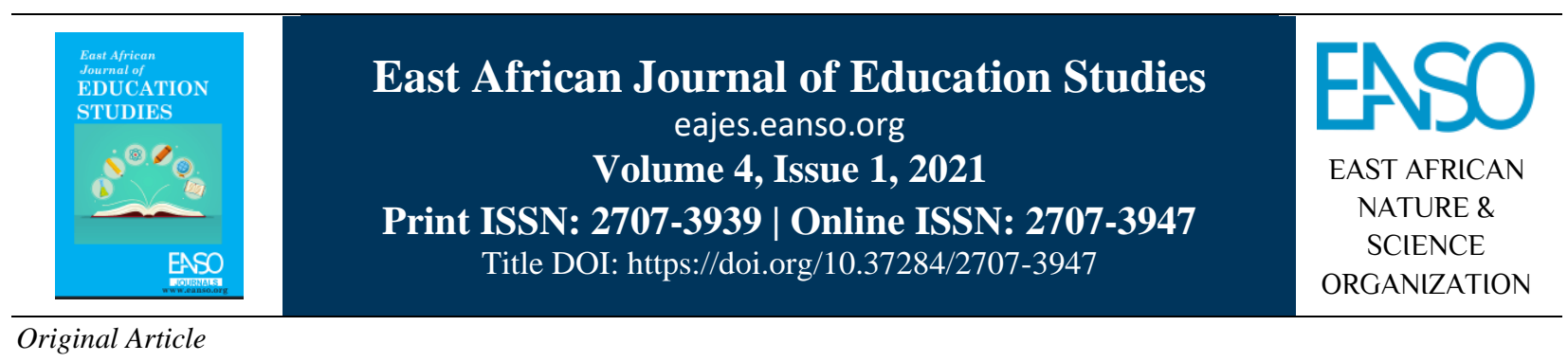

\title{
The Influence of Family Leadership on Girl- Child School Dropout.
}

\author{
Angelina Shoo ${ }^{1 *}$ \& Chrispina Lekule ${ }^{1}$ \\ ${ }^{1}$ St. Augustine University of Tanzania. P. O. Box 307 Mwanza, Tanzania. \\ * ORCID: https://orcid.org/0000-0001-8363-7418; Author for Correspondence Email: angelinaarchibald90@ gmail.com
}

Article DOI: https://doi.org/10.37284/eajes.4.1.455

\section{Date Published: ABSTRACT}

03 November 2021 Family leadership is one of the vital aspects that influences and determines both the wellbeing and successful education of a girl-child. Unfortunately, the role

Keywords: of family leadership in ensuring girls' education is oversimplified into getting

Family Leadership, girls enrolled in school rather than warranting their perseverance in learning

Girl Child,

School Dropout,

Marginalized, and successful completion. As a result, many communities in Tanzania, especially those in rural and marginalized areas are experiencing persistent girl-child school dropouts. It is against this standpoint that we sought to find out how family leadership may influence secondary school girls' dropouts. We also explored possible measures which should be employed to eliminate girl-

Self- Empowerment. child school dropouts. In conducting this study, we employed a mixed research approach and convergent parallel design. We collected data through interviews and questionnaires involving 143 respondents including girl students, teachers, heads of schools, and district educational officers. Our findings from this study indicate that while the government of Tanzania has made remarkable efforts to ensure girls' continuity and successful completion of secondary education, there are a number of factors hindering girls' continuity and completion of secondary education. Weak family leadership, the improper raising of the children, less emphasis and interest on the importance of girls' education, limited cooperation between family leadership were among the reason for continuous girl-child school dropout. Hence, based on our findings and the significance of girl's education as well as the role which parents should play in ensuring girls achievement of education, we appeal to various educational leaders, to make strategic efforts in raising more awareness among rural and marginalized communities about the importance of educating girls and the role of family leadership in bringing to an end the phenomena of girl-child school dropout which is catastrophic to the long-awaited sustainable development.

61| This work is licensed under a Creative Commons Attribution 4.0 International License. 
Moreover, we call upon all parents, to make intentional efforts in mentoring and influencing girls to strive towards achieving formal education.

\section{APA CITATION}

Shoo, A., \& Lekule, C. (2021). The Influence of Family Leadership on Girl- Child School Dropout. East African Journal of Education Studies, 4(1), 61-73. https://doi.org/10.37284/eajes.4.1.455.

\section{CHICAGO CITATION}

Shoo, Angelina, \& Chrispina Lekule. 2021. "The Influence of Family Leadership on Girl- Child School Dropout". East African Journal of Education Studies 4 (1), 61-73. https://doi.org/10.37284/eajes.4.1.455.

\section{HARVARD CITATION}

Shoo, A. \& Lekule, C. (2021) "The Influence of Family Leadership on Girl- Child School Dropout", East African Journal of Education Studies, 4(1), pp. 61-73. doi: 10.37284/eajes.4.1.455.

\section{IEEE CITATION}

A. Shoo, \& C. Lekule, "The Influence of Family Leadership on Girl- Child School Dropout", EAJES, vol. 4, no. 1, pp. 61-73, Nov. 2021.

\section{MLA CITATION}

Shoo, Angelina, \& Chrispina Lekule. "The Influence of Family Leadership on Girl- Child School Dropout". East African Journal of Education Studies, Vol. 4, no. 1, Nov. 2021, pp. 61-73, doi:10.37284/eajes.4.1.455.

\section{INTRODUCTION}

A family is regarded as the first school in which every child is first educated. Being the first school, it is also the main determinant of the future of the children. This is to say that a family is the most powerful agent which significantly influences the educational development of all children that go through this first school as they transition to a formal societal school. It is probably for this reason that Monga et al., (2015) suggested that family should be considered and recognized indispensable in the growth of any person but most significant of the child's (girl) schooling and right to education. This means that a good family environment may be useful in handling other negative influences in the education of girl students. Monga et al. (2015), further contends that school dropout of a child (girl) has a substantial association with the nature of family environment and leadership. Further, the fact is supported by Chenge, Chenge, and Maunganidze (2017), who argued that parent's educational level and educational aspirations for their children (girls) is believed to be an estimator of their girls' likelihood of leaving education before graduating, parents who are educated enough are aware regarding the importance of a girl child to have education can make an environment which supports their girl children to successfully complete their education.

It is undeniable that the structure and style of family leadership in which a girl child grows have a significant influence on the child's life and it does determine their perseverance or drop out of school (Mutua, 2014). According to Chenge et al. (2017), family structure generally includes two parents or single parents with their offspring and other members such as stepparents or grandparents. In this case, parents and other adult members make a family leadership team. When the family leadership team is consistent and they work together for the wellbeing of their children, the likelihood is that the children will get a good foundational education from the family and the likelihood to persevere in their education is higher. On the contrary, as Chenge et al., further argue, when the family structure is drastically changed due to divorce or death which brings undesired separation, it means that the family leadership is changed and the life of the children, particularly girls will never be the same. It is likely for this reason that Chugh (2011) argued regular changes in family leadership and structure, greatly affect a child's relationship with their parents and 
can greatly influence their chances of dropping out of secondary school because it limits the amount of time parents and children spend together as well as the corresponding parental care and attention to their children's education activities reduces.

It is from this endeavour that several efforts have been made by the government of Tanzania to reduce school dropouts and ensure that girls complete their secondary education. For instance, every government circular on education implements quality education as a prerequisite for any programme implementation (Hakielimu, 2010). Such programs include the introduction of free basic education for all (primary education and lower secondary school) in 2015, the circular aimed at ensuring the provision of free secondary education to all including girls (right to education Initiatives, 2016). Moreover, different stakeholders like Hakielimu and women activists such as TAMWA, TAWLA, and Msichana Initiatives have been advocating for girl children's right to education through policy formulation and campaigns. Such efforts have enhanced the number of girls enrolled in schools to increase in recent years. For example, Hakielimu (2011) has been advocating for the right of the girl children who leave or from school because of pregnancy. It suggests that girl child students who dropped out of school due to pregnancy should be given another opportunity and be encouraged to continue with their studies after giving birth.

Despite all the efforts done by government and nongovernmental organizations to ensure support for girls to pursue formal education as a right to life and basic necessity of their wellbeing, statistics reveal that girl students are still leading in school dropout. According to Basic Education Statistics (BEST) (2012-2016), 48.5 percent of girl students dropped out of secondary school in 2015, and in the following year in 2016, there was a very minor difference with a dropout of 47.37 percent. The cases were recorded for both the government and private secondary schools. In addition to this, in
2019, World Bank data revealed that the dropout of students still exists especially among girls whereby less than one-third of the girls who enter lower secondary school graduate. They further said that most of them dropped out of school due to family problems, pregnancy, and lack of basic necessities as well as government policies and sexual harassment. Hence, given this situation and the long-term effects which as educators we can foresee, we contend that there is a need to respond appropriately to address this problem and avoid any further loss of the country's workforce that may result in a nation full of illiterate women. It is for this reason that we conducted this study to find out how family leadership influences girls' dropouts in public secondary schools. In addition, we explored possible measures to address to the problem.

\section{LITERATURE REVIEW}

In conducting this study, a thorough review of both theoretical and empirical literature was done. Hence different literature sources were critically reviewed and synthesized for this study. To conduct this study poor family socialization theory was adopted. According to Rumberger and Lim (2008), poor family socialization theory is a theory developed by Battin-Pearson et al. (2000). The theory focuses on family practices and expectations as an influence on students' dropout. Rumberger (1983), as cited in Danovska (2018), argues that family background and poverty are the main reasons why children feel the pressure to drop out of school and to participate in activities that contribute to the family income. Hakielimu (2013), Rumberger (1983), and Denovska (2018) noted that parental level of education, parents' divorce, family stress, and parental behaviour also have a significant influence on students' school dropout.

This theory is instrumental in understanding the influence of family leadership on school dropout of girl students in Tanzania. The theory declares that different factors which are likely to influence school dropout of the girl student are in situations where

63| This work is licensed under a Creative Commons Attribution 4.0 International License. 
family leadership has certain weaknesses. The theory indicates that the parent's education level, parents' behaviour, and control in the family have an influence on school dropout.

\section{Understanding Family Leadership and School Dropout}

\section{Family Leadership}

Family leadership has been discussed differently by various scholars. For instance, according to Murray (2011), family leadership is when parents support their sons and daughters to find their own identity, make a decision, make choice, and have an aspiration for their future. In addition to this, Reynolds and John (2012), family leadership involves someone who is a family member with personal experience in using resources or cervices to strengthen his or her family and speak as well as an act from their perspective as a family member. Also, according to Ommolo (2013), Family leadership refers to the person responsible and accountable for everything that goes on within the family which is the smallest social institution in the society. In support to this, (Mutua, 2014; Zekele et al., 2020), argues that most of the family with a child-headed or single parent headship that is mother or father is due to social problems such as divorce, separation of family or death of one parent or both. Therefore, based on the meaning given by scholar's Family leadership can generally be referred to as a person who is responsible and accountable in maintaining the development of the welfare of the family in all aspects such as education-wise, socially, economically, and culturally.

\section{School Dropout}

The concept of school dropout is not new. It is actually one of the aspects which have been studied highly by various scholars across the globe. Due to many studies and the contexts in which the studies were conducted, the term has come to be understood and defined differently. De Witte et al. (2013) as cited in Fernandez-Suarez, et al. (2016), conceptualizes school dropout as a situation whereby learners terminate their studies without obtaining minimal credentials. According to Devkota and Bagale (2015) school, dropouts refer to the children who leave school or college before they complete their studies. Also, Chugh (2011) as cited in Devkota and Bagale (2015) defines school dropouts as young children, who enrol in the school and for some reasons other than death leave school before completing the grade or without transferring to another school. Given different ideas on school dropout as a situation or a student unable to complete his or her studies, generally, school dropout can be defined as a situation in which a student leaves school before completion or graduation due to different reasons.

\section{How Family Leadership Influences on Secondary School Dropout}

It is an undeniable truth that a family where a child is born and/or raised is the first and foremost school in which he or she begins the learning process and builds interest in further expanding what they are learning by joining others in formal schooling. Based on this standpoint, it is fair to argue that family leadership has a significant influence on what becomes of the child once in school. According to various scholarly works which we reviewed for the purpose of this study, the act of parents neglecting their children and having less value for education has highly led to school dropout of students particularly girls (Omollo, 2013). Likewise, in a study conducted in India by Sathwika and Reddy (2019), a number of students, mostly female, drop out of secondary school due to lack of parental interest in educating their girl-child. This finding is an indication that the power of parental leadership in influencing their children's way of life is significant. Hence, parental lack of interest in educating girls automatically socializes them (girls) to give less value to formal education, thus leading to possibilities for school dropouts. 
Family leadership is a crucial recipe that contributes to the productive continuity of children in school. According to various studies, when families resist the value of education, the likelihood is that their children will also see no value in education and will eventually drop out of school (Ghazi et al., 2011; Dakwa et al., 2014). According to Mutua (2014), the level of education of a parent matter in the state of education of a child; thus, if parents' education is low, their valuing of education will also be low. As a result, children from such families will most likely drop out because of lack of parental motivation and also lack of role models. This fact is supported by Ananga (2011) who saw parent's education as the determinant of the education of their offspring. In Ananga's view, the higher the education of parents, the greater the chances of perseverance of their children in school. Likewise, Chenge, et al. (2017), in a study conducted in Zimbabwe found that family leadership contributed to school dropout. According to these scholars, when family leadership is poor, its influence on children is jeopardized. Misunderstanding in the family especially between parents has a deleterious impact on the children particularly girls. In critical cases of misunderstanding between parents, children tend to lose focus on their studies and later on may drop out of school. Chenge et al. further found that family leadership may change when divorce or the death of a parent occurs. This influences school dropout rates because the structure of family leadership will also change into a single-parent family or step-parent family. This makes some of the single parents to lower their attention in raising their children since some of the parents only focus more on their work and forget to give attention to their children's education. In such a situation, children and especially girls are likely to engage in various activities as a survival strategy which may, later on, lead them to drop out of school.

Likewise, Mutua (2014) conducted a study whose findings revealed that most students from singleparents, those living with step-parent or grandparents are more likely to drop out of school than those growing up in their immediate families and with both parents. It is very likely that children living with extended family members are likely to develop low self-esteem, lack parental care and support and they are psychologically disturbed such that they are unable to concentrate on school work. Likewise, Ananga (2011) study, revealed that poor parenting style deters girls from school due to their unconcerned attitudes towards the schooling of their children. Ananga (2011,) further revealed that living with biological parents does not guarantee that a girl student would stay in school up to completion. It is also true that some parents neglect the responsibility of ensuring the education of their children because of social problems they experience such as family conflict. Also, according to Küçüker (2018), in many cases, school dropout is associated with female students due to family insecurity towards the child. Some parents tend to think and believe that children's morals will deteriorate while in school because of the long distance from home to school some of the parents withdraw their girls from school because they do not want them to run the same bus with boys.

\section{Measures Taken to Eliminate the Dropout of Secondary School Girl Students}

It is evident that most secondary school girl students encounter a lot of factors that influence them to drop out of school. Therefore, there must be steps to be taken at least to reduce some of the hindrances or completely eradicate them so that they can study comfortably and complete their secondary education. The following measures have been shown in different related literatures to help reduce or eliminate school dropouts among girl students.

\section{Financial Assistance}

Financial assistance is one of the measures that literature has shown to be effective in ensuring that girls successfully complete their secondary education. Financial assistance can be in offered in different ways as it is shown in various literature. In 
government schools, free education is provided to the students, whereby in these schools, there is normally provision of mid-day meals, so that students do not have to worry about bringing their meals from home. The parents are only required to provide their children uniforms, books and stationery, school bags, and travel expenses. Also has been the initiation of schemes geared towards offering scholarships and financial assistance to these students (Rwechungura, 2014; Kapur, 2018). As a result of this, most girls are encouraged to pursue their secondary education until they complete it.

\section{Education and Campaign on Importance of Girl's Education}

The provision of awareness on the importance of education for girls to the families and society, in general, has been overlooked (2016). Rwechungura (2014) and Rutakinikwa (2016) further argue that clubs should be introduced in the community where girls shall be able to participate and give their views concerning their education. Education to parents on the issue concerning child labour especially during school hours should also be given (Subrahmanyam, 2016).

\section{Provision of Guidance and Counselling to Girl Students}

Guidance and counselling services should be given to girls at home as well as at school to minimize or eliminate the chances of them getting into the temptation to drop out of school due to the influence of their peers. In a study conducted by Rutakinikwa (2016), the findings showed that teachers should practice the principles of guidance and counselling they learned in universities and colleges to help eliminate the chances of the girls dropping out of school. Parents should also learn to have talks with their girls on different challenges they are going through as they grow into adulthood as well as on a proper selection of friends who do not influence them to go astray.

\section{Construction of Dormitories and Hostels for Girl Students}

Hostels and dormitories should be built to accommodate girls near the school to minimize or completely curb the risks of them dropping out because of the temptation and obstacles girls face at home or on the way to school. A study conducted by Tanzania Youth Vision Association (2017) and Rutakinikwa (2016) suggested that, in order to eliminate secondary school girls' dropout, schools should be provided with transport or hostels constructed to accommodate students (girls) who walk long distances because they lack bus fare or feel uncomfortable studying at the home environment.

\section{RESEARCH METHODOLOGY}

To achieve the purpose of this study, we adopted a mixed research approach and a convergent parallel research design. The use of this approach allowed us to use not only different methods of data collection and analysis but also it enabled us to collect a wider range of data for a deeper understanding of the problem. Furthermore, the approach provided us an extra room to use several data collection methods as well as merging the information obtained to provide clear answers to the research problem. To ensure the reliability of the findings, this study employed both closed-ended and open-ended questionnaires as well as a semistructured interview. A sample size of 143 respondents was involved in data collection. The sample was made up of 93 girls, 46 teachers from three schools. Additionally, three heads of school and 1 educational officer were also involved in this study. Purposive sampling technique was used to select key informants for interviews such as Education officers and head teachers while simple random sampling was used to select girl-students and teachers.

66| This work is licensed under a Creative Commons Attribution 4.0 International License. 


\section{FINDINGS AND DISCUSSIONS}

In our endeavour to understand how family leadership influence secondary school girls' dropout, questionnaires contained question where teachers and students were asked if family leadership has an influence on secondary school girl's dropout. The findings revealed that parents/guardians as family leaders also to some extent influenced most of the girls in public secondary schools to drop out mostly because of their negligence.

Figure 1: Influence of Family Leadership on Secondary School Girl's Dropout

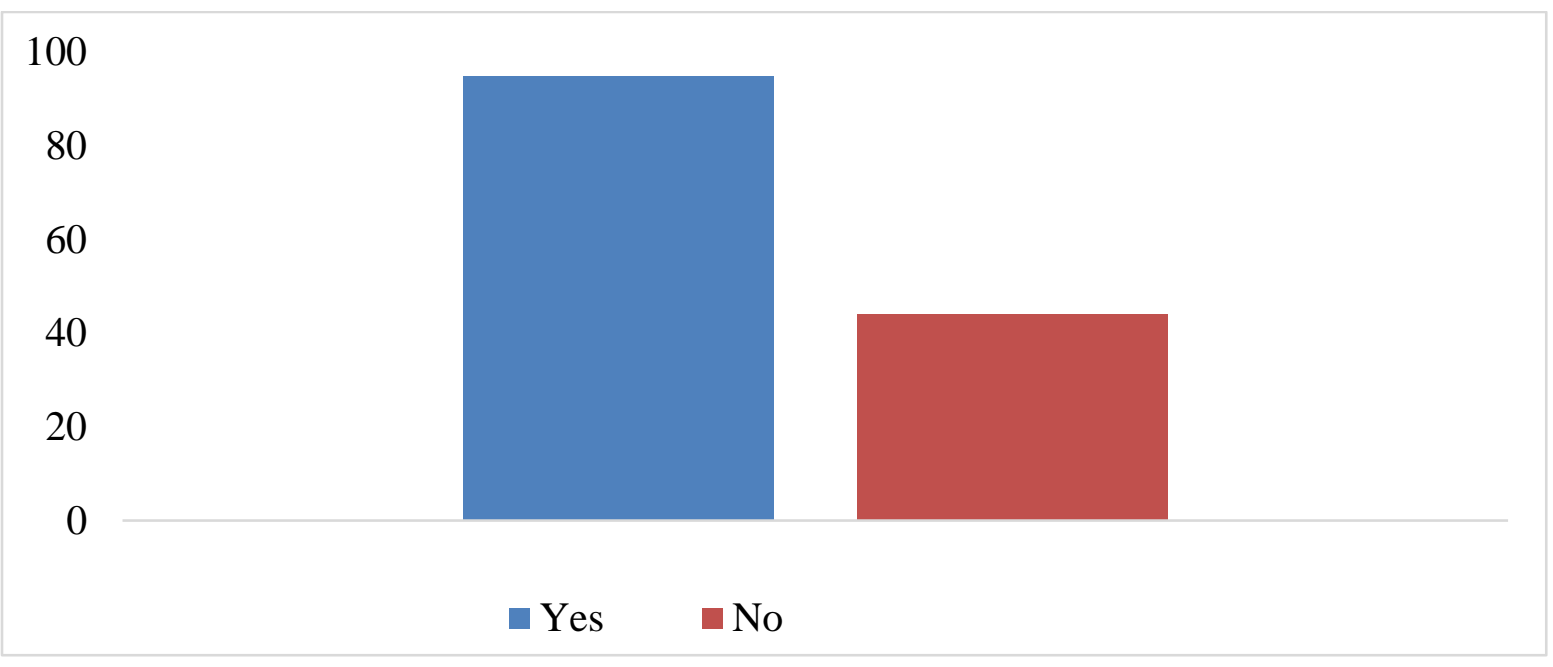

Figure 1 indicates that about 95 percent of the respondents agreed that parents/guardians as family leaders had an influence on secondary school girls' dropout. However, 44 respondents disagreed that parents/guardians contributed to girls' dropout in secondary school. In relation to this, the majority of respondents raised issues such as parents' lack of interest in formal education, negligence of parents in monitoring academic development of their girls, lack of cooperation with their daughters' teachers, and weak family leadership as ways on how parents/guardians influence girls' dropout in secondary school.

\section{Parent's Less Interest in Educating Girl Child}

Lack of parental interest in education was indicated to be one of the most influencing factors to girl students in dropping out of secondary education. Information provided by participants showed that some of the parents still lived in the era when only religious education was important to a child, and especially for girls. Thus, they failed to support their girls to complete their secondary school education. As a result of this girls end up dropping out of secondary school. Regarding parents less interest in education, one of the participants noted, "Some parents/guardians are still ignorant on the importance of formal education because to them 'Madrasa' is the most important, thus very few parents are eager to support their girls in continuing with their secondary education". Additionally, one of the participants questioned the interest of some parents in education by arguing that "You might find a parent/guardian who is unable to afford good uniform for her girl but can afford her "madrasa" "costumes". This shows that, since the study area is mostly dominated by the Islamic religion, lack of interest in formal education by some parents/guardians make them to withdraw their support to their girls' education so that they can stay at home and attend religious education. This study is supported by the poor family socialization theory as identified by Battin-Pearson et al. (2000) whose arguments focus on family practices and 
expectations as an influence on students' dropout (Rumberger, 1983 as cited in Danovska, 2018).

Additionally, similar issues were raised on the influence of family leadership on secondary school girl's dropouts. It was noted that there is a relationship between the level of education of parents and interest in education. The study required girls to indicate the level of education of their parents, whereby the responses indicated that the majority of parents did not go to school or only had primary education, while few of them had secondary education or higher education. Furthermore, respondents said that a parent's interest in education matches with one's level of education. This means that some of the parents/guardians who are less interested in education had a low level of education and tended to influence most of the girls to drop out of secondary school. In line with this, one of the participants was quoted saying "In our schools most of the girls come from the families whose parents have a low level of education or did not go to school at all, thus, they barely motivate them to go to school. Parents/guardians sometimes support their girls to stay at home by telling them that education is not a source of success". This indicates that parents and guardians with no education do not see the importance of schooling and its wastage of time, especially to girls. Thus, girls lack encouragement from their parents even when facing some hardships in their schooling and the only option for them was dropping out of secondary school. This was supported by Mutua (2014), who commented that most of the parents with a lower level of education are less interested in education thus they are less concerned with the education of their children (girls) and they are not acting as role models to them and the consequences are girls do not find the reasons to be in school leading to dropout. Also, according to Danovska (2018), poor family socialization theory argues that family practice and expectations influence students' dropout where the theory place parents and guardians have an influence on secondary school dropout especially to most of them with lower or no education. Some of these parents either advise their girls to drop out of school or to use indirect ways to make the girls drop out voluntarily.

\section{Cooperation between Parents or Guardians and Teachers}

Poor cooperation between parents/guardians as family leaders with teachers and school administration in ensuring proper education development of the girl students was discovered to have influenced to secondary school dropout for girls' students. Teachers and school heads reported that only a few parents come when they are called for meetings and fewer of them come to make follow-ups on the academic development of their girls. One of the participants was noted that; "Parents think that after bringing their children to school, their responsibility is over, and what is left is for the teachers and head of school to play their part". Therefore, this statement was meant to demonstrate that, because there is no total cooperation between parents and teachers in ensuring education to girls, the problem of girls dropping out of school will not end. Baker et al. (2016) supported by saying that parents/guardians influenced secondary school girls' drop out because they are not involved in the schooling activities and only a few parents show up at the school when needed because they are too busy with other personal duties. Hence, in understanding these arguments, it is evident that a lack of cooperation from parents makes the load on reducing dropout of girls even heavier because teachers find themselves to be on different sides from that of a parent when dealing with a girl's education situation.

\section{Weak Family Leadership}

This study revealed that weak family leadership had a strong influence on secondary school girls' dropout. It was reported that most of the girls are raised by single parents, guardians (relatives), or grandparents because their parents are deceased.

68| This work is licensed under a Creative Commons Attribution 4.0 International License. 
Consequently, they lack attention, care as well as guidance and counselling. The majority of the participants were noted saying that, unlike boys, girls need closer attention because of the obvious effect which occurs when they are neglected by their guardians or parents. The study revealed that girls need a high amount of time to regally talk with their parents so that parent would know their needs and ambitions as girls as well as be able to notice even when something is wrong. This is because most of the girls who dropped out of school here had become pregnant and they were living with their grandmothers who were too old or sick; so, they could not even raise these girls properly. These claims were confirmed by Keraita and Gakunga (2016) and Mutua (2014), who argued that most girls especially in day schools dropped out of school because such students have low self-esteem and they were not getting any encouragement or any psychological support from their parents through guidance and counselling. This is because most of them are too old and too religious or think that sitting down and talking with their daughters about life is absurd.

\section{Measures to Eliminate Secondary School Girls' Dropout}

In our endeavour to understand how family leadership may influence secondary school girls' dropout, it was evident that the issue of eliminating dropout of girl students in public secondary school is a responsibility of every stakeholder including government, parents, educators as well as girls themselves. Thus, different measures were raised by participants on how to curb the dropout of girls in public secondary school. Among them are;

\section{Building of Hostels and Dormitories}

Building dormitories for the girls was among the measures suggested by participants which would help to eliminate the high rate of their dropout in public secondary school. For example, one participant claimed that "building of hostels near the schools would enhance closer monitoring of the girls by their teachers, especially those who do not receive proper parental care as well as reduce high chances of them being influenced to drop out of school". Tanzania Youth Vision Association (2017) stresses that, in order to eliminate secondary school girls' dropout, schools should be provided with transport or hostels constructed to accommodate students (girls) who walk long distances because they lack bus fare or feel uncomfortable studying at the home environment. Also, Rutakinikwa (2016), suggested that the building of hostel and dormitories for girls in each school will provide a safe environment for studying for the female students.

\section{Educating Girls, Parents, and Community on the Importance of Education to Girls}

Educating girls, parents, and the community on the importance of education to Girls is another measure that was highly suggested in this study. That is, education should be provided to girls, parents as well as the community on the importance of education for girls. This would help to reduce or eliminate the dropout of girls in secondary schools. This means that, if this group of people is given education, it could reduce the number of girls who roam on the street during class hours, as well as reduce the number of girls who are looking for money by working in "Majumba ya starehe". In relation to this, one of the participants, argued, "Education should be provided especially to community, parents, and girls at large on the importance of education to girls". Hence in our understanding of this argument, it is evident that educating girls, parents, and the community at large on the importance of education to girls will increase awareness to each social group and highly help eliminate girls' dropout. This is supported by Rutakinikwa (2016), who suggested that awareness of the importance of education for girls should be provided to the families and society in general. This is because since literature has shown that some parents are less interested in education, thus tends to ignore most issues about their girl's schooling provision of education should include giving them

69| This work is licensed under a Creative Commons Attribution 4.0 International License. 
highlights on the importance of making follow up on the academic development of their girls. Therefore, Rwechungura (2014) and Rutakinikwa (2016) further commented that clubs should be introduced in the community and schools where girls will be educated on life skills to enable them to participate by giving their views concerning their education.

\section{Guidance and Counselling}

It was suggested that guidance and counselling should be given at school as well as at home by parents and guardians. This will help to encourage and motivate girls to attend school without thinking about dropping out of school. On this idea, one respondent wrote, "Guidance and counselling should be provided by teachers and parents in order to provide psychological support and saving girls from the danger of dropping out of school due to negative influences some of them are facing". Also, in the same line, another participant suggested, "We teachers, should play the role of a parent at school by listening to girls' problems and helping them solve them if they are within our capabilities". This means that there should be cooperation among teachers in helping girls by giving them advice at school on the issues challenging them which may result in their dropping out of school. Also, parents should play their role at home by talking with their girls freely even on some of the things that are embarrassing for a parent to talk with them. This fact is supported by Rutakinikwa (2016), who commented that counselling and guidance should be provided for school girls at home as well as at school so as to minimize or completely eliminate the chances of them being negatively influenced by their peers. Rutakinikwa further argued that teachers should practice the principles of guidance and counselling they learned in university and college to eliminate girls' dropout out in their schools

\section{Government Support}

Given the significance of girls' education, as found by this study, apart from the family, the government has a role to play in eradicating girls' dropout. First, it should do so by creating and ensuring the implementation of education policies that will hold accountable those who drop out of school without proper reasons. Also, laws should be made to make accountable those who influence girls to drop out of school without their will. Basing on this fact, one of the participants concurring with this suggestion, said; "Government should be responsible to induce very painful punitive measures on those parents who are catalysts for girls' dropouts in secondary schools". This idea was also reflected in the words of another participant who explained that since local authorities have been working tirelessly in ensuring students are not roaming unnecessarily during school hours, therefore, they should to place more attention to our girls by ensuring that an environment that endangers their education is not created. Also, they should hold accountable those who will be found tempting them or found with them in the street without formal permission from school during school hours. Therefore, in our understanding of this argument, it means that local authorities including the ward education office, the village council, and others should work hand in hand in eliminating secondary school girls' dropout by revealing those who in one way or another play part in contributing to girls dropping out of secondary school. Also, Tanzania Youth Vision Association (2017), commented that to get rid of students (girls) dropout, the people with the help of the local government authorities should report any dropout cases for police investigation and to ensure that legal enforcement and criminalizing of any parent or community member who contributes to girls drop out are affected. 


\section{Cooperation between Parents and Teachers}

These study respondents emphasize on cooperation among parents and teachers as a means to eliminate secondary school girls' dropout. This was confirmed by a teacher who insisted that cooperation among parents and teachers should be enhanced so that they can together monitor closely the development of education of a girl student both at home as well as at school. This is through working together in monitoring and discussing girls' education matters through attending teacherparents' meetings and by making follow-up with teachers at school regularly on the progress of the girls. Similar claims were made by another participant who suggested that "There is need for high levels of cooperation among parents and teachers to ensure that girls are motivated enough and have the necessary needs which motivate them to stay at schools". This statement meant that there is an opportunity for parents to work together with teachers in helping girls with the problem they are going through so as to reduce or eliminate the probability of their dropout in secondary school. Teacher-parent cooperation is highly encouraged because it helps in identifying and solving the female students' problems, encourages female students' education development and reduces female dropout in schools.

\section{CONCLUSION AND RECOMMENDATION}

Based on our findings and what we have disused so far, it is fair to conclude that family leadership has a significant influence on the successful education of girls. In most family's parents/guardians are the heads of the family but in other circumstance, a child can be the head of the family due to the role which circumstances force them to play. Therefore, parents/ guardians influenced the dropout of girls in secondary schools because parents and guardians tend to focus on their jobs and at times tend to completely forget about their children's (girls) education. Also, some of the girls who lived with their grandparents, girls tend to play the role of the household leader by providing for the family as well as taking care of the family. This situation jeopardizes girl's education as they have to concentrate more on how they can earn the living for the entire family. Based on this situation it is evident that girl's education, especially those from marginalized communities, are still lagging behind in education the fact which compromises the wellbeing of the entire nation. In our view, the nation cannot achieve its vision of sustainable development while girls are continually legging behind in terms of formal education. Therefore, more efforts should be made to make sure that girls equally gate their share of the national cake in terms of education which is believed to be emancipatory.

To overcome the challenges which girls from rural, vulnerable, and marginalized families and communities are still facing in relation to ensuring achievement of education, we recommend and humbly appeal to the government to take immediate action by strengthening and ensuring effective implementation of policies and circulars which safeguard the rights of women and also to take appropriate measures which will ensure girls success in education. Moreover, heads of schools should find the necessary means which will encourage parents to fully collaborate with teachers in supporting girls to persevere in school. For example, heads of schools should prepare motivational workshops and seminars which will involve parents so that they can share ideas and get training on how they can better be involved in supporting their girl child. Lastly, parents should take time to make follow up on the education of their girls by regularly checking their academic progress. Also, parents should be upfront in motivating and counselling and advising girls on the importance of education in their lives. Moreover, parents should make an effort of getting closer to their daughters to encourage transparency in a manner that they can get to know the kind of friends they have so that they can advise them accordingly. This will help in reducing the rate of school dropout

71| This work is licensed under a Creative Commons Attribution 4.0 International License. 
among girls. Finally, we appeal, to senior educators and academicians in the country to consider the issue of gender disparity which is partly due to the number of girls who drop out of school as critical and a matter of urgency which should be addressed by educating families on the importance of educating girls, and when applicable to establish scholarships to support girls' education.

\section{REFERENCES}

Ananga, E. D. (2011). Dropping out of school in southern Ghana: the push-out and pull-out factors. Ghana; Centre for International education

Baker, L.T., Wise, J., Kelly, G. \& Skiba, J.R. (2016). Identifying barriers: Creating solutions to improve family engagement. School Community Journal, 26(2), 161-184

Battin-Pearson, S., Newcomb, D. M., Abbott, D. R., \&Hill, G. K. (2000). Predictors of early high school dropout: A test of five theories. Journal of Educational Psychology, 92(3), 568-582

Chenge, P. R., Chenge, E. \& Maunganidze, L. (2017). Family factors that contribute to school dropout in Rushinga district in Zimbabwe. International Journal of Law, Humanities and Social Science, 1(4), 87-105.

Chugh, S. (2011). Dropout in secondary education. New Delhi: National University of Educational Planning and Administration.

Dakwa, F., Chiome, C. \& Chabaya, A. R. (2014). Poverty-related causes of school dropout-Dilrma of the girl child in rural Zimbabwe. International Journal of Academic Research in Progresive Education and Development, 3(1), 233-242. Doi:10.6007/JARPED/v3-i1/792

Danovska, K. (2018). Reasons behind children dropout of primary school with unequal socioeconomic preconditions (The Case of Kitui
Central District. Bachelor thesis, Sodertons University).

Devkota, S. P \& Bagale, S. (2015). Primary education and dropout in Nepal. Journal of Education and Practice, 6(4), 153-157.

Fernandez-Suarez, A., Herrero, J., JuarrosBasterretxea, J. \& Rodriguez-Diaz, J. F. (2016). Risk factors for school dropout in sample of juvenile offenders. Front. Psychol.7:1993. doi: 10.3389/fpsyg.2016.01993

Ghazi, S. R., Ali, R., Shahzad, S., Shahzada, G., \& Nawaz, K. (2011). Socio-Economic Factors as a Cause of Children Dropout at Primary Level. Mediterranean Journal of Social Sciences, 2(3), 531-531.

Hakielimu (2010). How to ensure educational success for girls: They have the right to complete their studies. Dar es Salaam: Hakielimu.

Kalinga, T. S. (2013). Causes of the Dropout in Secondary School in Tanzania: The Case Study of Mbeya, Dar es Salaam and Kilimanjaro Regions (Doctoral dissertation, The Open University of Tanzania).

Kapur, R. (2018). Factors affecting girl child education. University of Delhi, Department of

Adult, Continuing Education \& Extension.

Keraita, J. O. \& Gakunga, K. D. (2016). Factors influencing girl's dropout in public boarding and day secondary school in Masaba north districtKenya. International Journal of Economics, Commerce and Management, iv (8), 490-507

Küçüker, E. (2018). Reasons for dropout of girls from the formal secondary education living in rural areas. Education and Science, 43(195), 97117. doi 10.15390/EB.2018.7537

Monga, O. P., Monga, A., \& Monga, O. P. (2015). Family and School Dropouts: A Socio- 
psychological Observation. American International Journal of Research in Humanities, Arts and Social Sciences.

Mutua, K. F. (2014). Household factors influencing students' dropout in public secondary school (The Case of Kitui Central District. Master's thesis, The University of Nairobi). Retrieved from http://Monga, O.. Accessed on 16/06/2020 on 10:40am.

Murray, P. (2011). Developing Family Leadership. Centre of welfare reform publishers. Retrieved from https://www.centreforwelfarereform.org. Accessed on 26/06/2020 on 12:14pm.

Omollo, A. E. (2013). Socio-Economic Factors Influencing Students Drop Out in Public Secondary Schools in Rongo District, Migori County, Kenya (Doctoral dissertation, University of Nairobi,).

Reynolds, C. M. \& John, J. (2012). Core competencies of family leaders: A guide for families and organizations. Kansas City: Missouri Family Resource Center.

Right to Education. (2016). Tanzania Implements Free Education Policy for Secondary Education. Right to Education Initiatives. Retrieved from https://www.right- to- education.org/news/tanza nia- implements- free- education- policy- secon dary-education Accessed on 12/06/2020 on 11:50am.

Rumberger, R. W., \& Lim, S. A. (2008). Why students drop out of school: A review of 25 years of research.

Rutakinikwa, L. N. (2016). Factors Influencing Secondary School Girls DropOut in Bagamoyo District in Coast Region, Tanzania (Doctoral dissertation, The Open University of Tanzania).

Rwechungura, J. K. (2014). An exploratory study of the factors contributing to school dropout among girls in Temeke district of Dar es Salaam,
Tanzania (Master's thesis, University of Cape Town).

Sathwika, B. \& Reey, G. R. (2019). A study on adolescent girl dropout in Mahabubnagar district of Telangana state,India. International Journal of Current Microbiology and Applied Sciences, 8(2), 474-480.

Subrahmanyam, G. (2016). Gender Perspectives on Causes and Effects of School Dropout. Stockholm: Swedish International Development Cooperation Agency.

Tanzania Youth Vision Association. (2017). Report of the Survey on Girl's School Dropout in the Regions of Dodoma, Singida, Lindi and Pwani. Dar es Salaam.

URT (2016). Basic Education Statistics in Tanzania (BEST): National Data, Ministry of Education and Vocational Training. Dar es Salaam. Tanzania.

World Bank. (2019). Tanzania secondary education quality improvement project (SEQUIP). Washington-DC: The International Bank for Reconstruction and Development.

Zeleke, G. M., Terefe, B., Haile, E. G., \& Ejara, H. (2020). Child-Headed Household in EthiopiaThe Case of Addis Ababa City and Adama Town in Ethiopia. International Journal of Social Sciences, 9(2), 87-106.

73| This work is licensed under a Creative Commons Attribution 4.0 International License. 